\title{
Northern Borneo stalagmite records reveal West Pacific hydroclimate across MIS 5 and 6
}

\author{
Stacy A. Carolin ${ }^{\mathrm{a}, 1, *}$, Kim M. Cobb ${ }^{\mathrm{a}}$, Jean Lynch-Stieglitz ${ }^{\mathrm{a}}$, Jessica W. Moerman ${ }^{\mathrm{a}}$, Judson W. \\ Partin $^{\text {b }}$, Syria Lejau ${ }^{c}$, Jenny Malang ${ }^{c}$, Brian Clark ${ }^{c}$, Andrew A. Tuen ${ }^{\text {, Jess F. Adkins }}{ }^{\mathrm{e}}$ \\ ${ }^{\text {a }}$ School of Earth and Atmospheric Sciences, Georgia Institute of Technology, Atlanta, GA, 30332, USA \\ ${ }^{b}$ Institute for Geophysics, Jackson School of Geosciences, University of Texas, Austin, TX, 78758, USA \\ ${ }^{c}$ Gunung Mulu National Park, Sarawak, Malaysia \\ ${ }^{d}$ Institute of Biodiversity and Environmental Conservation, Universiti Malaysia Sarawak, 94300 Kota Samarahan, \\ Malaysia \\ ${ }^{e}$ Division of Geological and Planetary Sciences, California Institute of Technology, Pasadena, CA, 91125, USA \\ *Corresponding author at: Department of Earth Sciences, University of Oxford, South Parks Road, \\ Oxford, OX1 3AN, UK \\ Email address: stacy.carolin@earth.ox.ac.uk (S.A. Carolin) \\ ${ }^{1}$ Present address: Department of Earth Sciences, University of Oxford, Oxford, OX1 3AN, UK
}

\section{Keywords}

- $\quad$ Speleothem; stable isotopes; glacial cycles; Termination 2; penultimate interglacial; tropical west Pacific 


\section{ABSTRACT}

Over the past decades, tropical stalagmite $\delta^{18} \mathrm{O}$ records have provided valuable insight on glacial and interglacial hydrological variability and its relationship to a variety of natural climate forcings. The transition out of the penultimate glaciation (MIS 6) represents an important target for tropical hydroclimate reconstructions, yet relatively few such reconstructions resolve this transition. Particularly, comparisons between Termination 1 and 2 provide critical insight on the extent and influence of proposed climate mechanisms determined from paleorecords and model experiments spanning the recent deglaciation. Here we present a new compilation of western tropical Pacific hydrology spanning 0-160 kyBP, constructed from eleven different U/Th-dated stalagmite $\delta^{18} \mathrm{O}$ records from Gunung Mulu National Park in northern Borneo. The reconstruction exhibits significant precessional power in phase with boreal fall insolation strength over the 0-160 kyBP period, identifying precessional insolation forcing as the dominant driver of hydroclimate variability in northern Borneo on orbital timescales. A comparison with a network of paleoclimate records from the circum-Pacific suggests the insolation sensitivity may arise from changes in the Walker circulation system. Distinct millennial-scale increases in stalagmite $\delta^{18} \mathrm{O}$, indicative of reduced regional convection, occur within glacial terminations and may reflect a response to shifts in inter-hemispheric temperature gradients. Our results imply that hydroclimate in this region is sensitive to external forcing, with a response dominated by largescale temperature gradients. 


\subsection{Introduction}

The hydrologic response to anthropogenic $\mathrm{CO}_{2}$ forcing in the Indo-Pacific Warm Pool, a densely populated region, remains highly uncertain. Ambiguity persists due to a combination of high natural variability in hydroclimate, the limitations of short instrumental records of precipitation, and climate model biases in the simulation of present-day rainfall distributions (eg. IPCC AR5, 2013). Hydroclimate reconstructions spanning the middle and late Pleistocene provide an opportunity to test the influence of several different climate forcings on tropical hydrology, with implications for hydroclimate sensitivity to past, present, and future greenhouse forcing.

Several long, tropical paleo-hydrology records from across the globe reveal the strong influence of precessional (23ky) insolation on tropical monsoon strength, with some of the earliest evidence coming from the Indian Ocean (Prell and Kutzbach, 1987). More recently, stalagmite oxygen isotopic records with excellent absolute age control from the tropicalsubtropical regions of Indo-China and South America (eg. Cruz et al., 2005; Wang et al., 2008; Cheng et al., 2013) have demonstrated strong precessional (23 ky) signals closely in phase with local summer insolation. These signals are likely related to large-scale, coherent shifts in regional monsoon systems, though the precise mechanisms underlying precessional rainfall $\delta^{18} \mathrm{O}$ variability remain a subject of controversy (e.g. Clemens et al., 2010; Caley et al., 2014; Liu et al., 2014). In northern Borneo, stalagmite $\delta^{18} \mathrm{O}$ records from Gunung Mulu National Park suggest that precession may be a dominant source of hydroclimate variability in the West Pacific Warm Pool (WPWP). During Marine Isotope Stage (MIS) 5a-c (70-100 kyBP) and the Holocene (0-10 kyBP), when precessional forcing is moderately strong, Mulu stalagmite $\delta^{18} \mathrm{O}$ minima align with equatorial boreal fall insolation strength maxima (Carolin et al., 2013). 
The extent of the influence of glacial boundary conditions relative to insolation forcing

on western tropical Pacific convection is unclear. Trends in the 0-100 kyBP Mulu stalagmite $\delta^{18} \mathrm{O}$ record showed little similarity with the trend in polar $\mathrm{CO}_{2}$ and temperature records once mean ocean $\delta^{18} \mathrm{O}$ variability due to ice volume changes had been removed from the stalagmite $\delta^{18} \mathrm{O}$ values (Carolin et al., 2013). Further, little correspondence between Mulu stalagmite $\delta^{18} \mathrm{O}$ and an index of Sunda Shelf areal extent was evident over the entire glacial cycle (Carolin et al., 2013). A Last Glacial Maximum (LGM) data-model inter-comparison, however, suggests the exposure of the Sunda shelf landmass as a first-order influence on large-scale tropical atmospheric circulation on glacial-interglacial timescales (DiNezio and Tierney, 2013). Termination 2 is an excellent target for additional inquiries regarding the relative contributions of glacial boundary conditions versus precessional insolation on equatorial western Pacific hydroclimate. While insolation forcing is relatively weak through the transition from the LGM into the deglaciation and through to the Holocene, large variations in insolation are coincident with the penultimate deglaciation.

On sub-orbital timescales, tropical-subtropical hydrological reconstructions and climate model studies confirm that abrupt climate change events have a profound impact on tropicalsubtropical hydrological patterns, primarily through meridional migrations of the ITCZ and the major monsoon systems. Over the last deglaciation, for example, speleothem records from southeastern China, northern Borneo, Indonesia, and northern Australia, provide a meridional transect of sites in the western Pacific that all show millennial-scale shifts in $\delta^{18} \mathrm{O}$ coincident with North Atlantic cold intervals and in support of a southward migration of rainfall (Wang et al., 2001; Partin et al., 2007; Denniston et al., 2013a; Ayliffe et al., 2013). This pattern is 
repeated through MIS3, where records exist (Wang et al., 2001; Carolin et al., 2013; Denniston et al., 2013b).

One important difference between Borneo stalagmite $\delta^{18} \mathrm{O}$ and other southeast Asian stalagmite records is that the Borneo records reflect a relatively gradual trend into and out of maximum oxygen isotopic values (inferred as a dry period) associated with Heinrich Stadial 1 (HS1) (Partin et al., 2007). While the timing of the maximum dry event in northern Borneo is coincident with the other tropical-subtropical stalagmite records, the gradual trend in the record contrasts with other records' abrupt shifts into and out of their inferred weak (East Asian) or strong (Australian) HS1 monsoon intervals (Wang et al., 2001; Denniston et al., 2013a; Ayliffe et al., 2013). After H1, the Borneo stalagmites exhibit a relatively gradual deglaciation, with no clear Younger Dryas, suggesting that precession may dominate over remote forcing associated with the Bolling-Allerod and the Younger Dryas abrupt climate change events recorded in other tropical records (eg. Partin et al., 2015). Pronounced $\delta^{18} \mathrm{O}$ enrichments also characterize Borneo stalagmite $\delta^{18} \mathrm{O}$ records preceding Terminations 3, 4, and 5, suggesting that H1-like enrichments are closely associated with deglaciations of the more distant past. However, these records, like many proxy records spanning these intervals, are associated with relatively large age uncertainties, preventing a robust analysis of phase relationships between climate forcings and northern Borneo convection during this time interval.

Here we present a high-resolution 70-160 kyBP multi-stalagmite $\delta^{18} \mathrm{O}$ record from Gunung Mulu National Park, extending previously published Mulu $\delta^{18} \mathrm{O}$ records across Termination 2. This study offers a detailed record of inferred northern Borneo rainfall variability over the Stage 5 warm periods and the penultimate deglaciation. We examine the power spectral density and phase alignment of the $0-160 \mathrm{ky}$ records with $4^{\circ} \mathrm{N}$ insolation to determine the range 
of insolation forcing on northern Borneo rainfall through glacial/interglacial cycles. We then use the new Termination 2 Mulu $\delta^{18} \mathrm{O}$ records to investigate the relative strength of insolation forcing versus glacial boundary conditions, comparing the northern Borneo hydrologic responses across Terminations 1 and 2.

\subsection{Mulu Park's hydroclimate and karst}

Gunung Mulu National Park's limestone outcrops are located on the north-western side of Borneo island $\left(4^{\circ} 6^{\prime} \mathrm{N}, 114^{\circ} 53^{\prime} \mathrm{E}\right)$ (Fig. S1). The sample collection chambers are $\sim 120-200$ meters above sea level (masl) with variable overlying limestone depths of $\sim 50-150 \mathrm{~m}$. Rainfall averages $\sim 5000 \mathrm{~mm}$ annually, with no seasonality. As the ITCZ annually migrates north and south, Mulu's placement just north of the equator allows it to remain within West Pacific deep tropical convection year-round (Figure 1). Large shifts in convective activity over Mulu occur inter-annually, during ENSO extremes. During an El Niño event, warm SSTs in the central and eastern Pacific drive convective activity eastward, leading to drier conditions over northern Borneo. During a La Niña event, convection strengthens over northern Borneo (Cobb et al., 2007).

A 5-year daily rainfall collection study in Mulu shows present-day rainfall $\delta^{18} \mathrm{O}$ variability to reflect regional precipitation amount with significant basin-wide correlations at monthly and longer timescales (Moerman et al., 2013), in agreement with isotope-enabled climate model simulations (Lewis et al., 2010). Long-term monthly Mulu rainfall $\delta^{18} \mathrm{O}$ values demonstrate a weak semi-annual seasonal cycle (Moerman et al., 2013), despite a lack of seasonality in rainfall amount. The 5+ year rainwater isotope record shows two relative $\delta^{18} \mathrm{O}$ minima in the winter and summer seasons, and two relative $\delta^{18} \mathrm{O}$ maxima in the spring and fall seasons. As discussed in Moerman et al. (2013), the difference in isotopic values between the 
111 winter/summer months and the spring/fall months may be related to the wind dynamics in the

112 region. During the boreal summer (winter), Mulu is on the outer limits of the ITCZ and winds

113 have a strong southerly (northerly) trajectory (Figure 1). The longer moisture trajectories

114 associated with such winds may drive enhanced Raleigh fractionation leading to more depleted

115 rainfall $\delta^{18} \mathrm{O}$ during boreal summer and winter. Conversely, surface winds in northwestern

116 Borneo are virtually non-existent during spring and fall seasons, with more local sources of

117 moisture leading to relatively enriched rainfall $\delta^{18} \mathrm{O}$ (Moerman et al., 2013). On intra-seasonal

118 timescales, Moerman et al. (2013) shows multi-day rainfall anomalies in Mulu are closely

119 associated with the wet phases of the Madden-Julian Oscillation (MJO). On inter-annual

120 timescales, the Mulu rainfall $\delta^{18} \mathrm{O}$ timeseries is significantly correlated to ENSO indices, which

121 explain up to $40 \%$ of the monthly variance.

122

A 5-year record of biweekly dripwater $\delta^{18} \mathrm{O}$ values reflects the integration of amount-

123 weighted rainfall $\delta^{18} \mathrm{O}$ signals over the previous 3-10 months (Moerman et al, 2014), suggesting

124 a short residence time of dripwater $\delta^{18} \mathrm{O}$ relative to the multi-decadal to centennially resolved

125 reconstructions of stalagmite $\delta^{18} \mathrm{O}$ presented in this manuscript.

126

127

128

129

130

131

132

\subsection{Sample Collection}

Fallen stalagmites were collected during a 2012 expedition from (1) Fairy City chamber within Clearwater cave and (2) Whiterock cave (Fig. S1). After preliminary age analysis of the collected stalagmites, candidate samples were selected based on ${ }^{238} \mathrm{U}$ concentrations and extent of detrital contamination. New stalagmites analyzed in this study include FC12-12 (Fig. S2),

FC12-14 (Fig. S3), and FC12-15 (Fig. S4) from Fairy City chamber and WR12-01 (Fig. S5) and WR12-12 (Fig. S6) from Whiterock Cave. Analyses were also continued from previous studies 
133 into the lower sections of SC03 (Fig. S7) and SC02 (Fig. S8), which were collected from Secret

134 chamber within Clearwater cave during a 2006 expedition (Fig. S1).

135

136

137

138

139

140

141

142

143

144

145

146

147

148

149

150

151

152

153

154

155

\subsection{Analytical methods}

\subsection{Stable oxygen isotope measurements}

Oxygen isotopic analyses were conducted on 70-100 $\mu \mathrm{g}$ sample powders drilled at $0.2-$ $1 \mathrm{~mm}$ increments, depending on individual stalagmite growth rates, along the central growth axis of the stalagmites. Drilling was completed using a RoundTool Laboratories 1.6mm-diameter diamond-coated solid carbide end mill. Sampling procedure followed the continuous drilled "trough" technique along the growth axis to avoid aliasing. The $\delta^{18} \mathrm{O}$ ratios were analyzed on either a Finnigan 253 or a Delta V Plus, both equipped with Kiel devices at the Georgia Institute of Technology (long-term reproducibility of less than $\pm 0.07 \%$ o $(1 \sigma)$, as determined by compiling >800 in-house aragonite standards run over the course of this study). Selected sections of the stalagmites were run twice on both instruments to confirm calibration and reproducibility. All $\delta^{18} \mathrm{O}$ data are reported with respect to Vienna Peedee Belemnite (VPDB).

\subsection{U-Series isotope measurement and age calculation}

Radiogenic U/Th analyses were conducted on 150-420 mg sample powders, with sample size chosen based on the ${ }^{238} \mathrm{U}$ concentration of the sample. Age samples were drilled along visual stalagmite lamina using a RoundTool Laboratories $0.8-\mathrm{mm}$ or 1.6-mm diameter diamond-coated solid carbide end mill, with drill bit size chosen based on targeted sample volume. The U/Th dates were analyzed on a Finnigan Neptune MC-ICP-MS at the California Institute of Technology, following procedures outlined in Partin et al. (2007) and Carolin et al. (2013). The standard deviation $(2 \sigma)$ for the population of three or more procedural blank values within a batch was added in quadrature with the internal instrument standard error of the mean for all 
accepted isotope ratios $(2 \sigma)$. Measured concentrations and activity ratios are reported in Table S1 for all samples. Procedural blanks averaged $\sim 0.1-5 \%$ of sample for both ${ }^{230} \mathrm{Th}$ and ${ }^{234} \mathrm{U}$, with the spread due to the variation in $\mathrm{U}$ concentrations of the particular stalagmite samples.

The reported ages and their $2 \sigma$ uncertainties (Table S1) were estimated using a Monte Carlo simulation that accounts for the errors in all isotope ratios and the uncertainty in the initial ${ }^{230} \mathrm{Th} /{ }^{232} \mathrm{Th}$ ratio (Section 4.3 and Supplementary Materials). If the relative age error was greater than $2 \%$ of the calculated age, the age was not used in constructing a stalagmite's age model. Also, if a repeat dating sample was drilled directly above or below a previously analyzed sample, the date with the smaller age error was used in constructing the age model.

\subsection{Isochrons and ${ }^{230}$ Th-Corrected Age Model}

Isochrons were used to correct for the detrital contributions of ${ }^{238} \mathrm{U},{ }^{234} \mathrm{U}$, and ${ }^{230} \mathrm{Th}$ isotopes. Three or more co-precipitated samples with variable ${ }^{232} \mathrm{Th} /{ }^{238} \mathrm{U}$ ratios were analyzed on multiple stalagmites from multiple cave chambers for a total of 25 isochron-derived initial ${ }^{230} \mathrm{Th} /{ }^{232} \mathrm{Th}$ ratios (Figs. S9-S10 and Table S2). A large scatter of ${ }^{230} \mathrm{Th} /{ }^{232} \mathrm{Th}$ values occurs in Mulu stalagmites as a whole, indicating that more than one source of initial ${ }^{230}$ Th exists in our system. The detrital ${ }^{230} \mathrm{Th} /{ }^{232} \mathrm{Th}$ ratio for each stalagmite is therefore chosen based on multiple individual isochron values from either the same stalagmite, where available, or the same cave chamber. The detrital atomic ${ }^{230} \mathrm{Th} /{ }^{232} \mathrm{Th}$ ratios is assigned as follows, as determined in their original publications: SSC01 = $127 \pm 20$ ppm; SCH02 = $59 \pm 13$ ppm; BA04 = $55 \pm 5$ ppm; BA02 = $56 \pm 11$ ppm; SC03 and SC02 = $111 \pm 41$ ppm (2 $\sigma$ errors $)$ (Partin et al., 2007; Carolin et al., 2013). Fairy City stalagmites are assigned a detrital atomic ${ }^{230} \mathrm{Th} /{ }^{232} \mathrm{Th}$ ratio $=78 \pm 42 \mathrm{ppm}$ ( $2 \sigma$ errors) based on two isochrons (Supplementary Materials).

Due to relatively low levels of ${ }^{232} \mathrm{Th}$ in our Whiterock stalagmites, we were unable to calculate robust estimates of the initial ${ }^{230} \mathrm{Th} /{ }^{232} \mathrm{Th}$ ratio from isochrons (Fig. S10 and Table S2). 
180 In essence the drilled isochron samples were too 'clean' to give spread in the amount of ${ }^{232} \mathrm{Th}$

181 between different samples. To circumvent this problem, we compared overlapping $\delta^{18} \mathrm{O}$

182 timeseries from our two Whiterock stalagmites using a spread of initial ${ }^{230} \mathrm{Th} /{ }^{232} \mathrm{Th}$ ratios. We

183 used the $\delta^{18} \mathrm{O}$ timeseries near ages of low detrital contamination in at least one stalagmite as

184 targets, and assumed that both stalagmites' $\delta^{18} \mathrm{O}$ records trend up toward depleted $\delta^{18} \mathrm{O}$ values

185 concurrently over the penultimate deglaciation. The initial atomic ${ }^{230} \mathrm{Th} /{ }^{232} \mathrm{Th}$ for Whiterock that

186 produces the best fit between the two records is $60 \mathrm{ppm}$. We choose $20 \mathrm{ppm}$ as the initial atomic

$187{ }^{230} \mathrm{Th} /{ }^{232} \mathrm{Th} 2 \sigma$ error. Figure 2 shows a comparison between the $\delta^{18} \mathrm{O}$ timeseries using initial

188 atomic ${ }^{230} \mathrm{Th} /{ }^{232} \mathrm{Th}$ ratios equal to $60 \mathrm{ppm}$ (color) and bulk-earth $4.4 \mathrm{ppm}$ (black) for both WR12-

1891 and WR12-12. Ages largely affected by initial ${ }^{230} \mathrm{Th}$ are highlighted. We note that the $\delta^{18} \mathrm{O}$

190 maximum at 130 kyBP in WR12-1 is well constrained by several ages with low detrital Th

191 contamination.

192 The age models for the stalagmites in this study were constructed using the StalAge

193 algorithm (Scholz and Hoffman, 2011) (Supplemental Materials). Age-depth profiles for FC12-

194 12, FC12-14, FC12-15, WR12-01, WR12-12, and SC03 are provided in Fig. S2-S8 and S11.

195 Secret and Whiterock stalagmites have the greatest U concentration (100-200ppb and 200-

$196500 \mathrm{ppb}$, respectively) and the least detrital contamination, and therefore are associated with the

197 most robust age models $(0.4-1.0 \%(2 \sigma)$ relative age error, \pm 570 years $(2 \sigma)$ at Termination 2$)$.

198 FC12-14 and FC12-15 stalagmites have low U concentration (40-80ppb) and larger detrital

199 contamination, resulting in significantly larger age errors $(0.7-4.2 \%(2 \sigma)$ relative).

200

201

\subsection{Results}

202

$203 \delta^{18} \mathrm{O}$ records to $160 \mathrm{kyBP}$ (Figure 3). The stalagmite records are: WR12-01 (115.8-153.8 kyBP) 
and WR12-12 (113.9-144.4 kyBP) from Whiterock Cave, and FC12-12 (109.0-121.5 kyBP), FC12-14 (73.8-87.3 kyBP and 129.4-161.6 kyBP), and FC12-15 (139.9-164.0 kyBP) from Fairy City Chamber. We also extend previously published Secret Chamber stalagmites SC03 (103.5119.5 kyBP addition) and SC02 (94.1-99.0 kyBP addition). Throughout most of the 0-160 kyBP record, two to four individual stalagmite records' growth periods overlap, confirming reproducibility of the Mulu $\delta^{18} \mathrm{O}$ record at both orbital and millennial scales (Figure 4). One gap in the record exists between 100-103 kyBP, as we were unable to identify a sample that covered that time interval.

The composite Mulu timeseries exhibits notable offsets in $\delta^{18} \mathrm{O}$ between stalagmites, as observed in previous Mulu studies (e.g. Partin et al., 2007; Carolin et al., 2013). Drip water residence time and/or mixing in the vadose zone likely accounts for Mulu stalagmite offsets (Moerman et al., 2014). Partin et al. (2007) and Carolin et al. (2013) chose to reference all Gunung Buda/Mulu stalagmite $\delta^{18} \mathrm{O}$ records to Snail Shell Cave stalagmite SCH02, originally published in Partin et al. (2007), for consistency. Following that protocol, the new stalagmite $\delta^{18} \mathrm{O}$ records have been offset by the following amounts: WR12-01 and WR12-12 by $+0.3 \%$, FC12-12 and $\mathrm{FC} 12-14$ by $+0.35 \%$, and $\mathrm{FC} 12-15,+0.6 \%$.

The 0-160 kyBP Mulu stalagmite $\delta^{18} \mathrm{O}$ record exhibits significant orbital- and millennialscale features. The maximum $\delta^{18} \mathrm{O}$ enrichment at $130.6 \pm 0.6 \mathrm{kyBP}$ lasts $\sim 500$ years (age error determined by WR12-01, Figure 2). This event is reproduced in two Whiterock cave stalagmites and one Fairy City chamber (Clearwater cave) stalagmite (Figure 3), all positioned within a $\sim 10 \mathrm{~km}$ radius (Figure $\mathrm{S} 1$ ). The maximum $\delta^{18} \mathrm{O}$ enrichment falls at the end of the 6,000 -year "Weak Monsoon Interval" revealed in Chinese stalagmite records (eg. Cheng et al., 2009), an interval which spans most of the global penultimate deglaciation. The averaged $\delta^{18} \mathrm{O}$ values of 
227 the last interglacial period (we define here as $115-125 \mathrm{kyBP}$ ) are $\sim 0.5 \%$ more enriched (drier)

228 than the average last 500 yrs of the Mulu stalagmite $\delta^{18} \mathrm{O}$ record, with three stalagmite records

229 revealing an abrupt shift to depleted values (wet) from $\sim 121-119 \mathrm{kyBP}$, followed by a millennial-

230 scale shift toward enriched values (dry) from 119-116kyBP. Coming out of the last interglacial,

231 the Mulu stalagmite $\delta^{18} \mathrm{O}$ values demonstrate an overall trend toward more depleted (wetter)

232 values from 120 to $75 \mathrm{kyBP}$, reaching the most depleted period of the $0-160 \mathrm{kyBP}$ record (-1\%o

233 difference from present day) near the beginning of the MIS 5a to 4 transition ( 75 kyBP).

In an effort to distinguish between the effects of ice-volume-related changes in stalagmite

$235 \quad \delta^{18} \mathrm{O}$ versus hydroclimate-related changes in stalagmite $\delta^{18} \mathrm{O}$ at our site, we create an "ice-

236 volume corrected" $\delta^{18} \mathrm{O}$ record, $\delta^{18} \mathrm{O}_{\mathrm{IV}-\text { corr }}$, by removing mean ocean $\delta^{18} \mathrm{O}$ variability from the

237 Mulu stalagmite $\delta^{18} \mathrm{O}$ records. The mean ocean $\delta^{18} \mathrm{O}_{\mathrm{SW}}$ stack (Waelbroeck et al., 2002) aligns

238 reasonably well with $\mathrm{U}$-Th dated coral relative sea level (RSL) records for this time interval (see

239 Figure S14 for a detailed comparison between coral-derived sea level measurements and the

240 mean ocean $\delta^{18} \mathrm{O}_{\mathrm{SW}}$ stack, a proxy for ice volume, over Termination 1 and Termination 2). As

241 first recognized in Carolin et al. (2013), removing variability in mean ocean $\delta^{18} \mathrm{O}_{\mathrm{SW}}$ removes the

242 original Mulu $\delta^{18} \mathrm{O}$ trend toward more enriched $\delta^{18} \mathrm{O}$ values during MIS 3 evident on the original

243 record, shifting LGM values to values similar to the Mulu record's interglacial Stage 5e values

244 (115-125 kyBP) (Figure 4). Additionally, the maximum enrichment at Heinrich Stadial 1 (16.3

$245 \mathrm{kyBP}$ ) is shifted approximately $-1 \%$, while the large Mulu stalagmite $\delta^{18} \mathrm{O}$ enrichment at 130.6

246 kyBP remains unaffected, due to the difference in relative timing between ice volume decay and

247 the Mulu $\delta^{18} \mathrm{O}$ millennial enrichment across the two terminations (Figure 4).

Precessional-scale $\delta^{18} \mathrm{O}$ variability, previously recognized in the younger Mulu stalagmite

$249 \quad \delta^{18} \mathrm{O}$ records (Partin et al., 2007; Carolin et al., 2013), is evident throughout MIS 5 and 6 (70-160 
kyBP). Spectral analysis confirms a significant peak at the precessional period in both the

251 original and ice-volume corrected 0-160 kyBP records (Figure 5a, see Supplementary Materials).

252 The Mulu stalagmite $\delta^{18} \mathrm{O}$ records slightly lag the precessional component of $4^{\circ} \mathrm{N}$ SON

253 insolation (average September 1 - November 31 insolation) (Figure 5b, see Supplementary

254 Materials). It follows that Mulu stalagmite $\delta^{18} \mathrm{O}$ can also be described as out of phase with MAM

255 precessional insolation, or in phase with SON-MAM or MAM-SON insolation, as illustrated in

256 Partin et al., 2007 (Figure S12). The coherence between both the original and ice-volume

257 corrected Mulu stalagmite $\delta^{18} \mathrm{O}$ records and $4^{\circ} \mathrm{N}$ SON insolation at the precessional period is

$258 \quad 0.93$ and 0.94, respectively (Supplementary Materials).

\subsection{Discussion}

\subsection{Insolation control on northern Borneo convection}

Precessional forcing dominates the Mulu stalagmite $\delta^{18} \mathrm{O}$ records, in line with other tropical stalagmite $\delta^{18} \mathrm{O}$ records (eg. Cruz et al., 2005; Wang et al., 2008; Cheng et al., 2013). The longest of these comes from China, where stalagmite $\delta^{18} \mathrm{O}$ records spanning the last $224 \mathrm{ky}$ show a large, significant precessional signal at $\sim 23 \mathrm{ky}$ (eg. Wang et al., 2008). However the difference in phasing between the Chinese monsoon records and the northern Borneo tropical Pacific records is significant: Chinese stalagmite $\delta^{18} \mathrm{O}$ records slightly lag $4^{\circ} \mathrm{N} \mathrm{JJA}$ insolation (average June 1 - August 31 insolation), while Mulu stalagmite $\delta^{18} \mathrm{O}$ records slightly lag $4^{\circ} \mathrm{N}$ SON insolation (average September 1 - November 30 insolation), a significant difference in phase (Figure 5b).

The boreal fall precessional sensitivity of Mulu stalagmite $\delta^{18} \mathrm{O}$ may reflect changes in the properties of ENSO, given that ENSO variability explains the largest fraction of variance in the modern-day Mulu rainfall $\delta^{18} \mathrm{O}$ timeseries (Moerman et al., 2013). Indeed, other orbital-scale 
tropical Pacific ENSO-dominated paleoclimate records support a precessional modulation of Walker circulation strength. A 1.2 My-long equatorial Pacific marine sediment nitrogen isotope $\left(\delta^{15} \mathrm{~N}\right)$ gradient record, a proxy for upwelling rate and/or mean thermocline depth, has a strong signal at the precessional period (Rafter and Charles, 2012), as does an equatorial $240 \mathrm{ky}$-long marine record of the terrigenous fraction, a measure of local riverine runoff and precipitation, which was drilled from an eastern Indonesian site with weak seasonality (Dang et al., 2015). Early investigations with the Cane-Zebiak model of intermediate complexity suggested that ENSO variance may be sensitive to boreal fall insolation owing to zonally asymmetric heating of the tropical Pacific in the late boreal summer/early fall (Clement et al., 1999). In boreal fall, the ITCZ moves north off of the equator in the east Pacific and divergent winds return to the EEP. Uniform surface ocean heating from solar forcing therefore results in larger heating of the atmosphere in the WEP than the EEP. This asymmetric heating drives easterly winds and strengthens the Walker circulation. Clement et al. (1999) used this mechanism of zonally asymmetric atmospheric heating to relate Milankovitch forcing to tropical climate. The Zebiak-Cane ENSO model shows that a disruption of this seasonal cycle impacts ENSO frequency, due to nonlinear interactions that exist between the seasonal cycle and inter-annual variability (eg. Zebiak and Cane, 1987; Tziperman et al., 1997). Clement et al. (1999) ran the Zebiak-Cane ENSO model over 150ky at 10-day time-steps to show that Milankovitch forcing can produce a similar model response. The authors concluded that nonlinear interactions between the system's response to Milankovitch forcing on seasonal and inter-annual timescales yields a change in ENSO frequency, which they define as a mean tropical climate change due to the change in the statistics of events (Clement et al., 1999). A warm, El Niño (cold, La Niña) mean 
state occurred when the Zebiak-Cane ENSO model was forced by anomalous cooling (warming) in the late summer/early fall (Clement et al., 1999).

The high sensitivity of modern-day Mulu rainfall $\delta^{18} \mathrm{O}$ to ENSO variability (Moerman et al., 2013) makes changes in the strength of the Walker circulation a plausible explanation for the observed precessional signal in Mulu stalagmite $\delta^{18} \mathrm{O}$ that slightly lags SON insolation at the same latitude. High ENSO variance periods are likely to be manifested in a multi-decadal resolution Mulu stalagmite $\delta^{18} \mathrm{O}$ record as enriched $\delta^{18} \mathrm{O}$ periods because El Niño events produce higher amplitude Mulu rainfall $\delta^{18} \mathrm{O}$ anomalies than La Niña events (Moerman et al., 2013; 2014). Precessional-scale Mulu stalagmite $\delta^{18} \mathrm{O}$ maxima are indeed aligned with SON insolation minima throughout the 0-160 kyBP record (Figure 6), in agreement with the hypothesis that coupled minimum fall insolation and maximum spring insolation leads to a decrease in the zonal SST gradient, priming the tropical Pacific for warm, El Niño events. Further, a recent synthesis of paleo-ENSO reconstructions spanning much of the Holocene uncovers significant reductions in central Pacific ENSO variance during the 3-5 kyBP interval (Emile-Geay et al., 2015), a period when boreal fall insolation is at a maximum. However, available ENSO-resolving datasets are still too sparse to address whether the 3-5kybp minimum in ENSO properties was driven by precessional forcing or internal variability in the climate system. Nevertheless, both the LR04tuned (Lisiecki and Raymo, 2005) equatorial Pacific nitrogen isotope record (Rafter and Charles, 2012), a proxy for upwelling rate and/or mean thermocline depth, and the Mulu stalagmite $\delta^{18} \mathrm{O}$ record, a proxy for regional precipitation in an ENSO-affected area, are aligned with SON insolation (Figure 6). This agreement raises the possibility that the observed changes in Holocene ENSO properties uncovered in high-resolution proxy data reflect a sensitivity to boreal fall precessional forcing. 
Although the dominant peak in the Mulu stalagmite $\delta^{18} \mathrm{O}$ spectral analysis is at the precessional period, a smaller, yet significant, 11.5 ky peak (Figure 5a) suggests seasonal forcing as a possible driver of Mulu stalagmite $\delta^{18} \mathrm{O}$ variability. This is consistent with the fact that the sun passes overhead twice per year - once during spring and once during fall - which would imply a sensitivity to both spring and fall precessional forcing. Indeed, modern Mulu rainwater $\delta^{18} \mathrm{O}$ does exhibit a weak semi-annual cycle, with relative maxima in both boreal spring and fall (Moerman et al., 2013). Moerman et al. (2013) hypothesized that weak regional winds during the spring and fall seasons may result in shorter water vapor trajectories and less cumulative isotopic fractionation during these seasons. Further investigations into the mechanisms underlying the observed seasonal cycle in modern rainfall $\delta^{18} \mathrm{O}$, ideally employing an isotope-enabled atmospheric GCM, would help to clarify the role of seasonal rainfall $\delta^{18} \mathrm{O}$ variations in contributing to fall precessional sensitivity in Mulu stalagmite $\delta^{18} \mathrm{O}$.

\section{$6.2 \quad \delta^{18} \mathrm{O}$ Enrichments on Glacial Terminations}

Termination 1 and Termination 2 are both characterized by large $\delta^{18} \mathrm{O}$ maxima in Mulu stalagmite $\delta^{18} \mathrm{O}$, implying relatively dry conditions in the equatorial West Pacific during these times. Such events are reminiscent of the weak monsoon intervals identified in the stalagmite $\delta^{18} \mathrm{O}$ records from China (eg. Cheng et al., 2009). However, Mulu $\delta^{18} \mathrm{O}$ trends gradually into and out of the isotope maxima, unlike the more abrupt changes seen for the Chinese stalagmites. In addition, the timing of Mulu $\delta^{18} \mathrm{O}$ maxima with respect to atmospheric $\mathrm{CO}_{2}$, high latitude temperatures, and ice volume differs between the two Terminations (Figure 7). In Termination 1, Mulu reaches its $\delta^{18} \mathrm{O}$ maximum when $\mathrm{CO}_{2}$ and temperature have risen to only about $1 / 3$ of their interglacial values, while in Termination 2, Mulu reaches its $\delta^{18} \mathrm{O}$ maximum when $\mathrm{CO}_{2}$ and temperature have risen to almost their full interglacial values (see Supplementary Materials for 
341 discussion of ice core age models). This behavior is in contrast to the Chinese stalagmites, which

342 have been used to set the timing of terminations across a wide range of high latitude data (Cheng

343 et al., 2009).

344

345

346

347

348

349

350

351

352

353

354

355

356

357

358

359

360

361

362

363

The Mulu $\delta^{18} \mathrm{O}$ record tracks boreal fall insolation throughout both Terminations, a trend

toward more negative $\delta^{18} \mathrm{O}$ values as boreal fall insolation increases and boreal spring insolation decreases, despite the timing difference with other glacial forcings (Figure 7). This phasing implies that precessional insolation forcing might play a role in driving northern Borneo convection across major deglaciations. However, a direct relationship between northern Borneo convection and boreal fall insolation is not supported by the composite Mulu $\delta^{18} \mathrm{O}$ record (Partin et al., 2007; Meckler et al., 2012; Carolin et al., 2013; this study), which spans five glacial Terminations (Figure 8). The amplitudes of the Mulu $\delta^{18} \mathrm{O}$ maxima during Terminations do not correlate to the size of fall insolation peaks- Termination 5 (defined here as $\sim 431 \mathrm{kyBP}$ ) is one of the largest $\delta^{18} \mathrm{O}$ enrichments but insolation forcing is small (Figure 8). As such, while fall insolation is correlated with the timing of Mulu $\delta^{18} \mathrm{O}$ maxima, other factors likely determine the relative size of the anomaly.

The magnitude of enrichments in Mulu stalagmite $\delta^{18} \mathrm{O}$ across glacial Terminations may be related to movement of the annual position of the ITCZ. Several previous studies have invoked southward ITCZ migrations to explain tropical drying associated with Heinrich events during the last deglaciation and throughout MIS 3 (eg. Peterson et al., 2000; Wang et al., 2001; Partin et al., 2007; Cheng et al., 2013; Carolin et al., 2013; Ayliffe et al., 2013). A possible link between Mulu drying and inter-hemispheric climate changes comes from modeling studies implying a dynamical link between changes in cross-equatorial heat transport, driven by interhemispheric temperature gradients, and meridional shifts in the ITCZ (Kang et al., 2008; 
Donohoe et al., 2013). In general the ITCZ moves towards the warmer hemisphere, and the large differences in polar temperatures across deglaciations may have driven large meridional shifts in the ITCZ. Indeed, a correlation has been observed between the magnitude of Antarctic warmings and the duration of North Atlantic stadials in the polar ice cores (EPICA members, 2006). It is possible that during the early phases of deglaciations, the fact that warming in Antarctica preceded warming in the high-latitude Northern Hemisphere may explain large shifts in the position of the ITCZ that are reflected in the pronounced Borneo stalagmite $\delta^{18} \mathrm{O}$ enrichments. A related issue raised by our new record is the degree to which 100-ky power is evident in tropical precipitation. While there is no hint of the classic 'sawtooth' structure in the Chinese stalagmites, there is some indication of 100-ky cyclicity in the extended Mulu $\delta^{18} \mathrm{O}$ data, as well as tropical Pacific SST (Figure 8). We argue that any 100-ky cycle visible in the Mulu stalagmite $\delta^{18} \mathrm{O}$ records is principally due to two factors: the deglacial $\delta^{18} \mathrm{O}$ enrichments and the global ocean $\delta^{18} \mathrm{O}$ variance with glaciation. Subtracting the sea level effect from the Mulu $\delta^{18} \mathrm{O}$ record shows a nearly flat glacial to interglacial trend over the last 160ky (Figure 4). Notably, the minimum $\delta^{18} \mathrm{O}$ over the last cycle is at MIS 5a, not 5e where there is peak SST warming and highest $\mathrm{pCO}_{2}$. Indeed, spectral analysis of the $0-570 \mathrm{kyBP}$ Mulu $\delta^{18} \mathrm{O}$ record corrected for changes in mean ocean $\delta^{18} \mathrm{O}$ due to ice volume shows only a slightly significant signal at the 100-ky period, forced by the large and consistent $\delta^{18} \mathrm{O}$ enrichments at Terminations (Figure S13, Supplementary Materials). The weak effect of global boundary conditions on northern Borneo rainfall contrasts markedly with the strong correlation found between greenhouse gas forcing and tropical Pacific SSTs (e.g. Lea 2004; Herbert et al., 2010). However, model simulations also indicate that tropical hydrologic variability may vary independently of global ice volume changes, and is instead largely governed by changes in large-scale temperature gradients 
(Clement et al., 2004). Alternatively, SST responds more directly to changes in heat fluxes associated with glacial-interglacial variability. Other multi-hundred-thousand-year tropical hydrologic records also demonstrate significant signals at the precessional period with little power at the 100-ky period (eg. Tachikawa et a., 2011; Thomas et al., 2014; Dang et al., 2015). Models and proxy records suggest that exposure of the Sunda and Sahel Shelves drove changes in convection over Borneo (eg. DiNezio and Tierney, 2013), raising the prospect that inundation of the Sunda Shelf during glacial terminations may have contributed to the observed Mulu deglaciation $\delta^{18} \mathrm{O}$ enrichments. Indeed, there is probably a large change in the relative albedo and heat capacity of the Maritime Continent with glacial sea level change as this region has a large concentration of shallow seas. Additionally, exposure of the Sunda Shelf likely would have had an effect to some extent on the seasonal cycle of rainwater isotopes in Mulu. However, a comparison between the Termination 1 and Termination 2 sea level records reveals significant differences regarding the timing of Sunda Shelf inundation and Mulu $\delta^{18} \mathrm{O}$ enrichment. During Termination 1, Mulu $\delta^{18} \mathrm{O}$ trends into its large $\delta^{18} \mathrm{O}$ enrichment while sea level remains below $100 \mathrm{~m}$ and the Sunda Shelf remains exposed (Hanebuth et al., 2000). Alternatively, during Termination 2, Mulu $\delta^{18} \mathrm{O}$ trends into its large $\delta^{18} \mathrm{O}$ enrichment while the Sunda Shelf is being completely inundated (Figure S14; see Supplementary Materials). By $130 \mathrm{kyBP}$, the timing of the maximum Mulu $\delta^{18} \mathrm{O}$ enrichment on Termination 2, many coral records agree that the sealevel high stand has already been reached and that the Sunda Shelf is already flooded (Figure S14; see Supplementary Materials). Based on this evidence, the Mulu records suggest that neither exposure nor inundation of the Sunda Shelf on its own is causing large northern Borneo rainfall anomalies on glacial terminations, though we can't rule out a role for large climate 
409 sensitivity in this region as sea level flooding alters the local atmosphere's surface boundary

410 condition.

$411 \quad$ 7.0 Conclusions

412 The extended Mulu stalagmite $\delta^{18} \mathrm{O}$ record suggests that on orbital timescales, northern

413 Borneo hydrology is relatively insensitive to glacial-interglacial variability, and is largely

414 controlled by boreal fall precessional forcing. We hypothesize that the phase relationship

415 between Mulu $\delta^{18} \mathrm{O}$ and boreal fall insolation reflects changes in the strength of the Walker

416 circulation, perhaps reflecting forced changes in ENSO properties - a mechanism supported by

417 several other tropical Pacific records. The close alignment of Mulu $\delta^{18} \mathrm{O}$ with boreal fall

418 insolation is maintained through both Termination 1 and Termination 2, despite markedly

419 different phasing of glacial boundary conditions across each termination. However, the

420 amplitudes of large Mulu $\delta^{18} \mathrm{O}$ maxima that occur during Terminations do not correlate with the

421 size of fall insolation peaks, therefore factors other than $4^{\circ} \mathrm{N}$ boreal fall insolation strength likely

422 determine the relative size of the large Mulu $\delta^{18} \mathrm{O}$ Termination maxima. The large magnitude

423 and timing of the Mulu $\delta^{18} \mathrm{O}$ enrichments observed during glacial terminations present a

424 compelling target for paleoclimate modeling studies aimed at resolving the mechanisms of

425 glacial-interglacial variability. 


\section{Acknowledgements}

We thank Jessica Moerman, Danja Mewes, Eleanor Middlemas, and Sang Chen for fieldwork assistance, and all the staff at Gunung Mulu National Park World Heritage Site for their dedicated assistance during field expeditions. We also thank Guillaume Paris, Sophie Hines, James Rae, and Andrea Burke for their assistance in U-Th dating, and Hussein Sayani, Pamela Grothe, and Tammy Chang for their assistance in oxygen isotope measurements. The research was funded by NSF PECASE Award \#0645291 to KMC, NSF AGS award \#0903099 to JFA, and a NSF Graduate Research Fellowship to SAC. Permits for this work were granted by the Malaysian Economic Planning Unit, the Sarawak State Planning Unit, and the Sarawak Forestry Department. All data reported in this paper are archived at NCDC (ftp://ftp.ncdc.noaa.gov/pub/data/paleo/speleothem/pacific/gunung-mulu2015.txt). 


\section{Figure Captions}

438

439

440

441

442

443

444

445

446

447

448

449

450

451

452

453

454

455

456

457

Figure 1. Precipitation (shaded) and $1000 \mathrm{mb}$ wind (arrows) climatology maps for the tropical Indo-Pacific, adopted from Cobb et al., 2007. (A) Mean precipitation and winds for December through February (DJF). A $5 \mathrm{~m} / \mathrm{s}$ wind vector (shown in white box) is plotted for reference. (B) Same as (A) but for March through May (MAM). (C) Same as (A) but for June through August (JJA). (D) Same as (A) but for September through November (SON). CMAP precipitation (Xie and Arkin, 1997) and NCEP wind data (Kalnay et al., 1996) provided by the NOAA/OAR/ESRL PSD, Boulder, Colorado, USA, from their web-site at http://www.cdc.noaa.gov/.

Figure 2. Constraints on initial ${ }^{230} \mathrm{Th} /{ }^{232} \mathrm{Th}$ ratios for Whiterock stalagmite $\delta^{18} \mathrm{O}$ timeseries. (a) WR12-01 age sample ${ }^{232} \mathrm{Th} /{ }^{238} \mathrm{U}$ versus age plotted above $\delta^{18} \mathrm{O}$ versus age. Both sample ${ }^{232} \mathrm{Th} /{ }^{238} \mathrm{U}$ and $\delta^{18} \mathrm{O}$ timeseries are plotted using StalAge algorithm age models and StalAge error bars (Scholz and Hoffman, 2011). Data calculated using initial ${ }^{230} \mathrm{Th} /{ }^{232} \mathrm{Th}$ atomic ratio $=60 \mathrm{ppm}$ are plotted in orange, data calculated using initial ${ }^{230} \mathrm{Th} /{ }^{232} \mathrm{Th}$ atomic ratio $=4.4 \mathrm{ppm}$ (bulk earth) are plotted in black. Note a greater shift toward younger age occurs when samples contain high ${ }^{232}$ Th concentrations. Red circles highlight ages in which the 60ppm Th-ratio age lies outside the error bars of the bulk-earth Th-ratio age. Vertical dotted lines indicate points on $\delta^{18} \mathrm{O}$ timeseries corresponding to age samples with low ${ }^{232}$ Th concentrations ( $\left.<1000 \mathrm{ppt}\right)$. (b) Same as (a) but for WR12-12. (c) WR12-01 and WR12-12 age samples with error bars (Supplementary Materials) and $\delta^{18} \mathrm{O}$ timeseries. Age models were calculated using initial ${ }^{230} \mathrm{Th} /{ }^{232} \mathrm{Th}$ atomic ratio $=60 \pm 20$ ppm. Same vertical dotted lines as in (a) and (b). Ages of samples with ${ }^{232}$ Th concentrations $>1000$ ppt are filled white. 
458 Figure 3. Composite and individual Mulu stalagmite $\delta^{18} \mathrm{O}$ records. (a) Overlapping Mulu 459 stalagmite $\delta^{18} \mathrm{O}$ records using Stalage age models (Scholz and Hoffman, 2011): SC03 (red), 460 SC02 (navy), FC12-14 (dark red), WR12-12 (dark green), WR12-01 (orange), FC12-12 (pink), 461 and FC12-15 (purple), plotted with previously published stalagmite $\delta^{18} \mathrm{O}$ data from our site 462 (Partin et al., 2007; Carolin et al., 2013). (b) Individual Mulu stalagmite $\delta^{18} \mathrm{O}$ 463 records $\square \square \square \square \square \square \square \square \square$ plotted on top of a Mulu stack (black) (100-yr non-overlapping boxcar 464 averages). $\delta^{18} \mathrm{O}$ offsets are shown in boxes on each individual plot. $\delta^{18} \mathrm{O}$ offsets are chosen to 465 match the absolute value of SCH02, consistent with the prior use of SCH02 as a benchmark 466 (Partin et al., 2007). U/Th-based age samples plotted in corresponding colors, shown with $2 \sigma$ 467 uncertainty limits.

468

469

470

471

472

473

474

475

476

477

478 479

Figure 4. Original and ice-volume corrected 0-160 kybp Mulu stalagmite $\delta^{18} \mathrm{O}$ records. (a) Original and (b) ice-volume corrected Mulu stalagmite $\delta^{18} \mathrm{O}$ records (Partin et al., 2007; Carolin et al., 2013, this study). Ice-volume corrected Mulu records calculated by removing mean-ocean $\delta^{18} \mathrm{O}_{\mathrm{SW}}$ (Waelbroeck et al., 2002). (c) Mean ocean $\delta^{18} \mathrm{O}_{\mathrm{SW}}$ record constructed from temperaturecorrected Atlantic-Pacific-Indian ocean sediment benthic- $\delta^{18} \mathrm{O}$ stack (Waelbroeck et al., 2002). (c) was subtracted from (a) to construct (b).

Figure 5. Mulu stalagmite spectral analysis and phase wheel summary. (a) Percent power density from spectral analysis of original (grey) and ice-volume corrected (black) Mulu $\delta^{18} \mathrm{O}$ composite stalagmite 0-160 kyBP record (100yr sampling resolution) (Partin et al., 2007; Carolin et al., 2013; this study). (b) 23-ky period phase wheel diagram showing the phase alignment between the original and ice volume Mulu stalagmite 0-160 kyBP $\delta^{18} \mathrm{O}$ record (black arrows) and $4^{\circ} \mathrm{N}$ latitude insolation (Berger, 1978). JJA indicates average insolation from June 1 - 
August 31. Errors for Mulu across the 160ky interval are approximately $+/-300 \mathrm{yrs}$, which translates into phase errors of $+/-5$ degrees. The phase relationship with the benthic foraminifera $\delta^{18} \mathrm{O}$ stack (Lisiecki and Raymo, 2005), derived sea level (Waelbroeck et al., 2002), and the Chinese stalagmite $\delta^{18} \mathrm{O}$ records (Wang et al., 2001; 2008) is also indicated in the phase wheel diagram. Errors for Chinese stalagmite $\delta^{18} \mathrm{O}$ across the 160ky interval are similar to the Mulu stalagmite errors. Errors for the marine records are approximately $+/-4000 y r s$, which translates into phase errors of +/- 18 degrees. DPSS taper method spectral analysis and multi-taper method coherence were done using a Matlab script provided by Prof. Peter Huybers, (www.people.fas.harvard.edu/ phuybers/Mfiles/Toolbox/) (details provided in Supplementary Materials).

Figure 6. Comparison of both Mulu stalagmite $\delta^{18} \mathrm{O}$ records and equatorial Pacific marine sediment $\Delta \delta^{15} \mathrm{~N}$ records with $4^{\circ} \mathrm{N}$ SON insolation (average Sept. 1 - Nov. 30 insolation strength). (top) Contour plot of latitude $4^{\circ} \mathrm{N}$ insolation flux $\left(\mathrm{W} / \mathrm{m}^{2}\right)$ daily through the calendar year from 0-160 kybp. (middle) Mulu stalagmite $\delta^{18} \mathrm{O}$ records (Partin et al., 2007; Carolin et al., 2013; this study) with overlapping $4^{\circ} \mathrm{N}$ SON insolation. (lower) Equatorial Pacific marine sediment $\Delta \delta^{15} \mathrm{~N}$ records tuned to LR04 age model (Rafter and Charles, 2012) with overlapping $4^{\circ} \mathrm{N}$ SON insolation.

Figure 7. (left) Termination 1 paleorecord comparison. (a) Insolation forcing $\left(\mathrm{W} / \mathrm{m}^{2}\right)$ at $65^{\circ} \mathrm{N}$ boreal summer solstice (orange) and $65^{\circ} \mathrm{S}$ austral summer solstice (green) (Berger 1978). (b) Chinese $\delta^{18} \mathrm{O}$ stalagmite records on published age model (Wang et al., 2001; Wang et al., 2008). (c) Composite Mulu stalagmite $\delta^{18} \mathrm{O}$ records, original published (dark red) and ice-volume corrected (blue) (Partin et al, 2007; Carolin 2013) averaged in 100yr boxcar bins with 
overlapping $4^{\circ} \mathrm{N}$ SON insolation (average Sept. 1 - Nov. 30 insolation strength) (Berger 1978). (d) Marine sediment Mg/Ca SST reconstructions from WEP site ODP 806b (black) (Lea et al., 2000) and EEP site TR163-22 (grey) (Lea et al., 2006) on published age model. $\mathrm{SST}_{0 \mathrm{~K}}$ set as $29^{\circ} \mathrm{C}$ for site ODP $806 \mathrm{~b}$ and $24.3^{\circ} \mathrm{C}$ for TR163-22, per the present day SST listed in original publications. (e) $\mathrm{EDC} \mathrm{CO}_{2}$ records (Monnin et al., 2001) on the EDC3 timescale and Taylor Dome $\mathrm{CO}_{2}$ records (Indermühle et al., 1999) on the st9810 timescale (see Supplementary Materials for age model details) (f) Vostok ice core $\delta$ D records (Petit et al., 1999) on the Lemieux-Dudon timescale (see Supplementary Materials for age model details) (g) Coral relative sea level records plotted on top of mean ocean temperature-corrected $\delta^{18} \mathrm{O}$ records (Supplementary Materials, see Fig. S14). (right) Termination 2 paleorecord comparison. (a) same as left. (b) Sanbao stalagmite $\delta^{18} \mathrm{O}$ records (Wang et al. 2008; Cheng et al., 2009). (c) Composite Mulu stalagmite $\delta^{18} \mathrm{O}$ records, original (red) and ice-volume corrected (blue) (this study) averaged in 100yr boxcar bins with overlapping $4^{\circ} \mathrm{N}$ SON insolation (Berger 1978). (d) same as left. (e) Vostok ice core $\mathrm{CO}_{2}$ record (Petit et al., 1999). Age model determined by aligning Vostok ice core $\mathrm{CH}_{4}$ record with Sanbao $\delta^{18} \mathrm{O}$ record (see Supplementary Materials for details) (f) Vostok ice core $\delta$ D records (Petit et al., 1999). Age model determined by aligning Vostok ice core $\mathrm{CH}_{4}$ record with Sanbao $\delta^{18} \mathrm{O}$ record (see Supplementary Materials for details) (g) Same as left. Blue shading indicates the interval of deglaciation $\mathrm{CO}_{2}$ rise. The orange vertical dashed line marks the $65^{\circ} \mathrm{N} \mathrm{NH}$ summer insolation minimum prior to the Termination.

Figure 8. Comparison of $0-600 \mathrm{kyBP}$ global paleorecords. (a) Chinese stalagmite $\delta^{18} \mathrm{O}$ records (Wang et al., 2001; Wang et al., 2008; Cheng et al., 2009). (b) Timeseries of SON insolation flux (average Sept. 1 - Nov. 30 insolation strength) at latitude $4^{\circ} \mathrm{N}$ (Berger, 1978). Red arrows show 
524 timing of Mulu $\delta^{18} \mathrm{O}$ maxima on terminations. (c) Mulu stalagmite $\delta^{18} \mathrm{O}$ records (Partin et al., 525 2007; Meckler et al., 2012; Carolin et al., 2013, this study;). Records are not ice-volume 526 corrected. (d) Marine sediment Mg/Ca SST reconstructions from WEP site ODP 806b (black) 527 and EEP site TR163-19 (grey) on original published age model (Lea et al., 2000; 2004). (e) 528 Vostok $\mathrm{CO}_{2}$ records (Petit et al., 1999) on the EDC3 timescale (see Supplementary Materials for 529 age model details) (f) $\mathrm{Ca} / \mathrm{Sr}$ ratios (suggested indicator of Hudson Straight Heinrich layers) and $530 \mathrm{Si} / \mathrm{Sr}$ ratios (suggested indicator of different sources and/or glaciological processes than Hudson 531 Straight Heinrich layers) from XRF scan of IODP Site U1308 (reoccupation of DSDP 609) 532 ocean sediment core (Hodell et al., 2008). 


\section{References}

1. Ayliffe, L.K., Gagan, M.K., Zhao, J.X., Drysdale, R.N., Hellstrom, J.C., Hantoro, W.S., Griffiths, M.L., Scott-Gagan, H., St Pierre, E., Cowley, J.A., Suwargadi, B.W., 2013. Rapid interhemispheric climate links via the Australasian monsoon during the last deglaciation. Nat. Commun. 4.

2. Berger, A.L., 1978. Long-term variations of daily insolation and quaternary climatic changes. Journal of the Atmospheric Sciences 35, 2362-2367.

3. Caley, T., Roche, D.M., Renssen, H., 2014. Orbital Asian summer monsoon dynamics revealed using an isotope- enabled global climate model. Nat. Commun. 5.

4. Carolin, S.A., Cobb, K.M., Adkins, J.F., Clark, B., Conroy, J.L., Lejau, S., Malang, J., Tuen, A.A., 2013. Varied Response of Western Pacific Hydrology to Climate Forcings over the Last Glacial Period. Science 340, 1564-1566.

5. Cheng, H., Edwards, R.L., Broecker, W.S., Denton, G.H., Kong, X.G., Wang, Y.J., Zhang, R., Wang, X.F., 2009. Ice Age Terminations. Science 326, 248-252.

6. Cheng, H., Sinha, A., Cruz, F.W., Wang, X.F., Edwards, R.L.A., d'Horta, F.M., Ribas, C.C., Vuille, M., Stott, L.D., Auler, A.S., 2013. Climate change patterns in Amazonia and biodiversity. Nat. Commun. 4.

7. Clemens, S.C., Prell, W.L., Sun, Y., 2010. Orbital-scale timing and mechanisms driving Late Pleistocene Indo-Asian summer monsoons: Reinterpreting cave speleothem delta O-18. Paleoceanography 25.

8. Clement, A.C., Seager, R., Cane, M.A., 1999. Orbital controls on the El Nino/Southern Oscillation and the tropical climate. Paleoceanography 14, 441-456.

9. Clement, A.C., Hall, A., Broccoli, A.J., 2004. The importance of precessional signals in the tropical climate. Climate Dynamics 22, 327-341.

10. Cobb, K.M., Adkins, J.F., Partin, J.W., Clark, B., 2007. Regional-scale climate influences on temporal variations of rainwater and cave dripwater oxygen isotopes in northern Borneo. Earth Planet. Sci. Lett. 263, 207-220.

11. Cruz, F.W., Burns, S.J., Karmann, I., Sharp, W.D., Vuille, M., Cardoso, A.O., Ferrari, J.A., Dias, P.L.S., Viana, O., 2005. Insolation-driven changes in atmospheric circulation over the past 116,000 years in subtropical Brazil. Nature 434, 63-66.

12. Dang, H., Jian, Z., Kissel, C., Bassinot, F., 2015. Precessional changes in the western equatorial Pacific Hydroclimate: A 240 kyr marine record from the Halmahera Sea, East Indonesia. Geochemistry Geophysics Geosystems 16, 148-164. 
13. Denniston, R.F., Asmerom, Y., Lachniet, M., Polyak, V.J., Hope, P., An, N., Rodzinyak, K., Humphreys, W.F., 2013a. A Last Glacial Maximum through middle Holocene stalagmite record of coastal Western Australia climate. Quaternary Science Reviews 77, 101-112.

14. Denniston, R.F., Wyrwoll, K.H., Asmerom, Y., Polyak, V.J., Humphreys, W.F., Cugley, J., Woods, D., LaPointe, Z., Peota, J., Greaves, E., 2013b. North Atlantic forcing of millennialscale Indo-Australian monsoon dynamics during the Last Glacial period. Quaternary Science Reviews 72, 159-168.

15. DiNezio, P.N., Tierney, J.E., 2013. The effect of sea level on glacial Indo-Pacific climate. Nature Geoscience 6, 485-491.

16. Donohoe, A., Marshall, J., Ferreira, D., McGee, D., 2013. The Relationship between ITCZ Location and Cross-Equatorial Atmospheric Heat Transport: From the Seasonal Cycle to the Last Glacial Maximum. J. Clim. 26, 3597-3618.

17. Emile-Geay, J., Cobb, K.M., Carre, M., Braconnot, P., Leloup, J., Zhou1, Y., Harrison, S.P., Correge, T., McGregor, H.V., Collins, M., Driscoll, R., Elliot, M., Schneider, B., Tudhope, A., 2015. Links between tropical Pacific seasonal, interannual and orbital variability during the Holocene. Nature Geoscience, doi:10.1038/ngeo2608.

18. EPICA Members, 2006. One-to-one coupling of glacial climate variability in Greenland and Antarctica. Nature 444, 195-198.

19. Hanebuth, T., Stattegger, K., Grootes, P.M., 2000. Rapid flooding of the Sunda Shelf: A lateglacial sea-level record. Science 288, 1033-1035.

20. Herbert, T.D., Peterson, L.C., Lawrence, K.T., Liu, Z.H., 2010. Tropical Ocean Temperatures Over the Past 3.5 Million Years. Science 328, 1530-1534.

21. Hodell, D.A., Channell, J.E.T., Curtis, J.H., Romero, O.E., Rohl, U., 2008. Onset of "Hudson Strait" Heinrich events in the eastern North Atlantic at the end of the middle Pleistocene transition (similar to $640 \mathrm{ka}$ )? Paleoceanography 23.

22. Indermuhle, A., Stocker, T.F., Joos, F., Fischer, H., Smith, H.J., Wahlen, M., Deck, B., Mastroianni, D., Tschumi, J., Blunier, T., Meyer, R., Stauffer, B., 1999. Holocene carboncycle dynamics based on CO2 trapped in ice at Taylor Dome, Antarctica. Nature 398, 121 126.

23. IPCC, 2013: Climate Change 2013: The Physical Science Basis. Contribution of Working Group I to the Fifth Assessment Report of the Intergovernmental Panel on Climate Change (eds Stocker, T. F. et al.) Cambridge Univ. Press, 2013.

24. Kalnay, E., Kanamitsu, M., Kistler, R., Collins, W., Deaven, D., Gandin, L., Iredell, M., Saha, S., White, G., Woollen, J., Zhu, Y., Chelliah, M., Ebisuzaki, W., Higgins, W., Janowiak, J., Mo, K.C., Ropelewski, C., Wang, J., Leetmaa, A., Reynolds, R., Jenne, R., 
Joseph, D., 1996. The NCEP/NCAR 40-year reanalysis project. Bull. Am. Meteorol. Soc. 77, $437-471$.

25. Kang, S.M., Held, I.M., Frierson, D.M.W., Zhao, M., 2008. The response of the ITCZ to extratropical thermal forcing: Idealized slab-ocean experiments with a GCM. J. Clim. 21, 3521-3532.

26. Lea, D.W., Pak, D.K., Spero, H.J., 2000. Climate impact of late quaternary equatorial Pacific sea surface temperature variations. Science 289, 1719-1724.

27. Lea, D.W., 2004. The 100,000-yr cycle in tropical SST, greenhouse forcing, and climate sensitivity. J. Clim. 17, 2170-2179.

28. Lea, D.W., Pak, D.K., Belanger, C.L., Spero, H.J., Hall, M.A., Shackleton, N.J., 2006. Paleoclimate history of Galapagos surface waters over the last 135,000 yr. Quaternary Science Reviews 25, 1152-1167.

29. Lewis, S.C., LeGrande, A.N., Kelley, M., Schmidt, G.A., 2010. Water vapour source impacts on oxygen isotope variability in tropical precipitation during Heinrich events. Climate of the Past 6, 325-343.

30. Lisiecki, L.E., Raymo, M.E., 2005. A Pliocene-Pleistocene stack of 57 globally distributed benthic delta O-18 records. Paleoceanography 20.

31. Liu, Z., Wen, X., Brady, E.C., Otto-Bliesner, B., Yu, G., Lu, H., Cheng, H., Wang, Y., Zheng, W., Ding, Y., Edwards, R.L., Cheng, J., Liu, W., Yang, H., 2014a. Chinese cave records and the East Asia Summer Monsoon. Quaternary Science Reviews 83, 115-128.

32. Meckler, A.N., Clarkson, M.O., Cobb, K.M., Sodemann, H., Adkins, J.F., 2012. Interglacial Hydroclimate in the Tropical West Pacific Through the Late Pleistocene. Science 336, 13011304.

33. Moerman, J.W., Cobb, K.M., Adkins, J.F., Sodemann, H., Clark, B., Tuen, A.A., 2013. Diurnal to interannual rainfall delta O-18 variations in northern Borneo driven by regional hydrology. Earth Planet. Sci. Lett. 369, 108-119.

34. Moerman, J.W., Cobb, K.M., Partin, J.W., Meckler, A.N., Carolin, S.A., Adkins, J.F., Lejau, S., Malang, J., Clark, B., Tuen, A.A., 2014. Transformation of ENSO-related rainwater to dripwater delta O-18 variability by vadose water mixing. Geophysical Research Letters 41, 7907-7915.

35. Monnin, E., Indermuhle, A., Dallenbach, A., Fluckiger, J., Stauffer, B., Stocker, T.F., Raynaud, D., Barnola, J.M., 2001. Atmospheric CO2 concentrations over the last glacial termination. Science 291, 112-114.

36. Partin, J.W., Cobb, K.M., Adkins, J.F., Clark, B., Fernandez, D.P., 2007. Millennial-scale 
trends in west Pacific warm pool hydrology since the Last Glacial Maximum. Nature 449, 452-U453.

37. Partin, J.W., Quinn, T.M., Shen, C.C., Okumura, Y., Cardenas, M.B., Siringan, F.P., Banner, J.L., Lin, K., Hu, H.M., Taylor, F.W., 2015. Gradual onset and recovery of the Younger Dryas abrupt climate event in the tropics. Nat. Commun. 6.

38. Peterson, L.C., Haug, G.H., Hughen, K.A., Rohl, U., 2000. Rapid changes in the hydrologic cycle of the tropical Atlantic during the last glacial. Science 290, 1947-1951.

39. Petit, J.R., Jouzel, J., Raynaud, D., Barkov, N.I., Barnola, J.M., Basile, I., Bender, M., Chappellaz, J., Davis, M., Delaygue, G., Delmotte, M., Kotlyakov, V.M., Legrand, M., Lipenkov, V.Y., Lorius, C., Pepin, L., Ritz, C., Saltzman, E., Stievenard, M., 1999. Climate and atmospheric history of the past 420,000 years from the Vostok ice core, Antarctica. Nature 399, 429-436.

40. Prell, W.L., Kutzbach, J.E., 1987. Monsoon variability over the past 150,000 years. Journal of Geophysical Research-Atmospheres 92, 8411-8425.

41. Rafter, P.A., Charles, C.D., 2012. Pleistocene equatorial Pacific dynamics inferred from the zonal asymmetry in sedimentary nitrogen isotopes. Paleoceanography 27.

42. Scholz, D., Hoffmann, D.L., 2011. StalAge - An algorithm designed for construction of speleothem age models. Quaternary Geochronology 6, 369-382.

43. Tachikawa, K., Cartapanis, O., Vidal, L., Beaufort, L., Barlyaeva, T., Bard, E., 2011. The precession phase of hydrological variability in the Western Pacific Warm Pool during the past 400 ka. Quaternary Science Reviews 30, 3716-3727.

44. Thomas, E.K., Clemens, S.C., Prell, W.L., Herbert, T.D., Huang, Y., Liu, Z., Damste, J.S.S., Sun, Y., Wen, X., 2014. Temperature and leaf wax delta H-2 records demonstrate seasonal and regional controls on Asian monsoon proxies. Geology 42, 1075-1078.

45. Tziperman, E., Zebiak, S.E., Cane, M.A., 1997. Mechanisms of seasonal - ENSO interaction. Journal of the Atmospheric Sciences 54, 61-71.

46. Waelbroeck, C., Labeyrie, L., Michel, E., Duplessy, J.C., McManus, J.F., Lambeck, K., Balbon, E., Labracherie, M., 2002. Sea-level and deep water temperature changes derived from benthic foraminifera isotopic records. Quaternary Science Reviews 21, 295-305.

47. Wang, Y.J., Cheng, H., Edwards, R.L., An, Z.S., Wu, J.Y., Shen, C.C., Dorale, J.A., 2001. A high-resolution absolute-dated Late Pleistocene monsoon record from Hulu Cave, China. Science 294, 2345-2348.

48. Wang, Y.J., Cheng, H., Edwards, R.L., Kong, X.G., Shao, X.H., Chen, S.T., Wu, J.Y., Jiang, X.Y., Wang, X.F., An, Z.S., 2008. Millennial- and orbital-scale changes in the East Asian 
monsoon over the past 224,000 years. Nature 451, 1090-1093.

49. Xie, P.P., Arkin, P.A., 1997. Global precipitation: a 17-year monthly analysis based on gauge observations, satellite estimates, and numerical model outputs. Bull. Am. Meteorol. Soc. 78, 2539-2558.

50. Zebiak, S.E., Cane, M.A., 1987. A model El-Nino southern oscillation. Monthly Weather Review 115, 2262-2278. 
Figures for:

Rainfall variability across MIS 5 and 6 revealed in northern Borneo stalagmite records

(Carolin et al.)
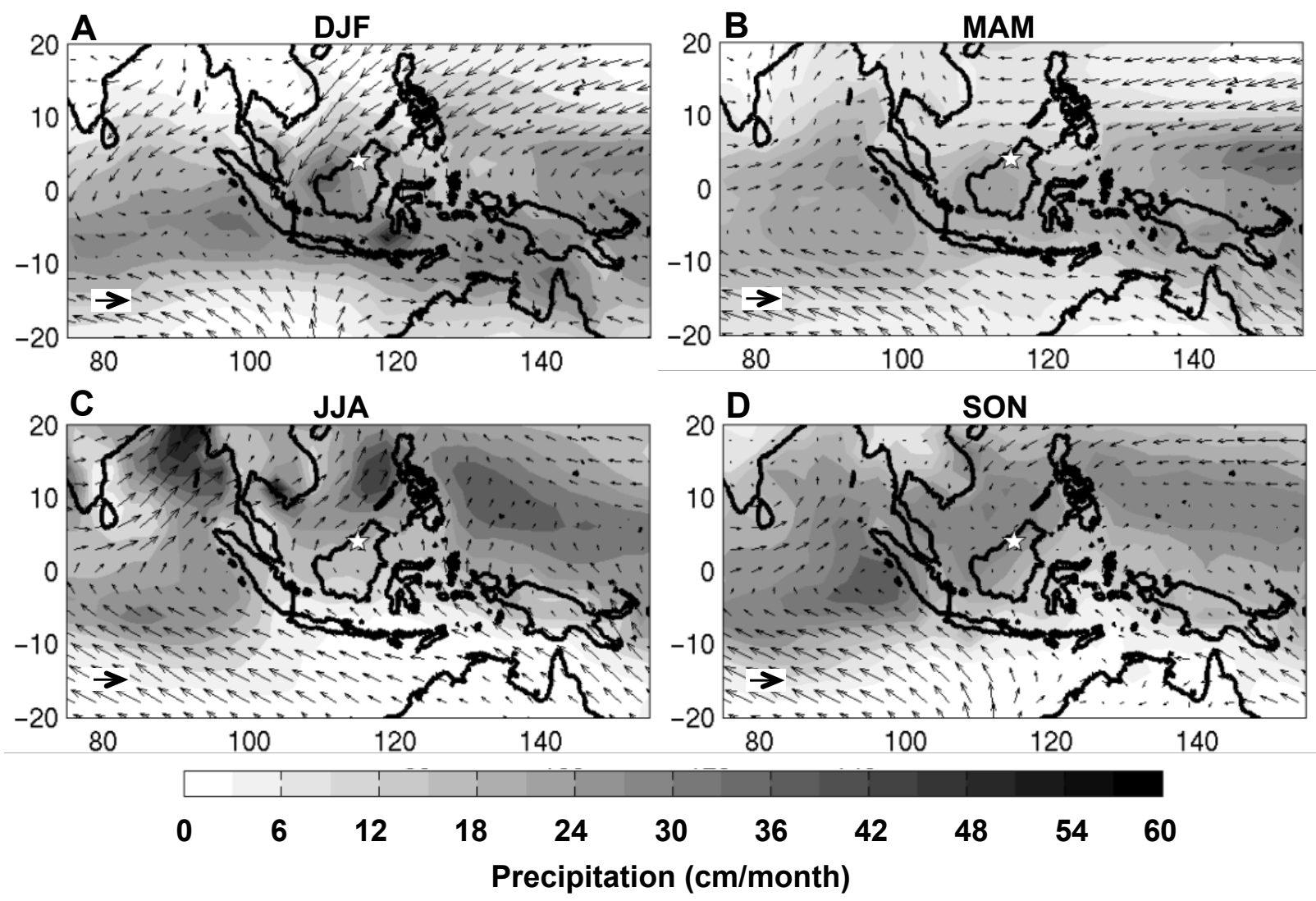

Figure 1. Precipitation (shaded) and $1000 \mathrm{mb}$ wind (arrows) climatology maps for the tropical Indo-Pacific, adopted from Cobb et al., 2007. 
a.

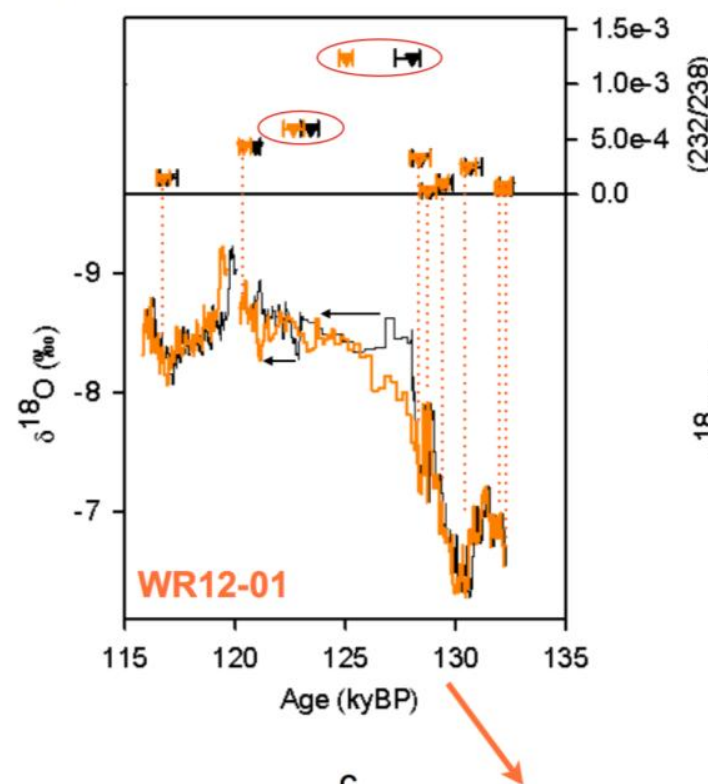

b.
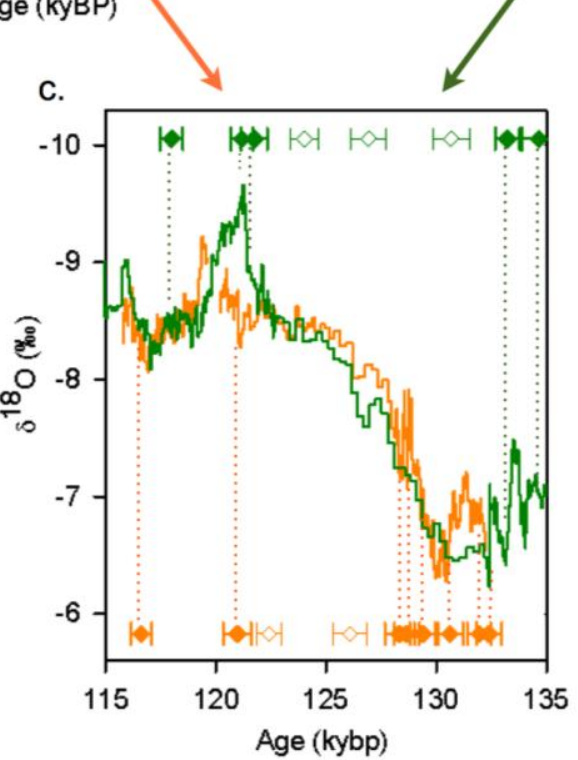
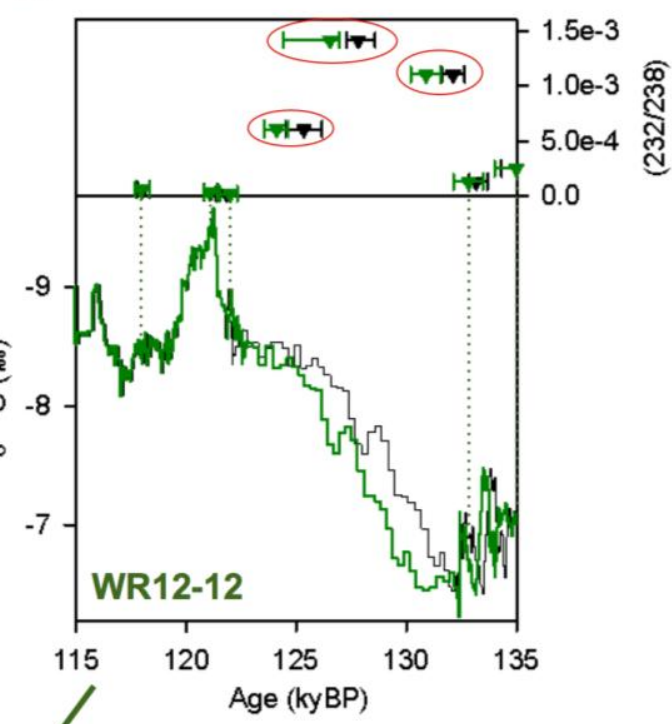

Figure 2. Constraints on initial ${ }^{230} \mathrm{Th} /{ }^{232} \mathrm{Th}$ ratios for Whiterock stalagmite $\delta^{18} \mathrm{O}$ timeseries. 


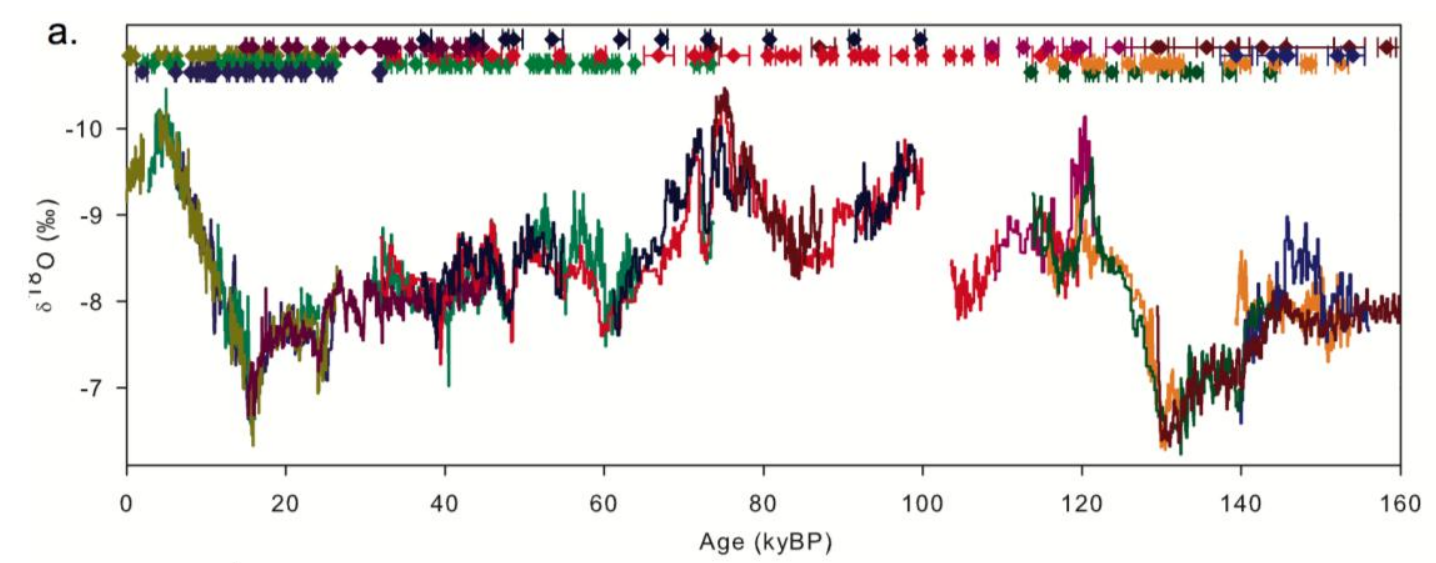

b.
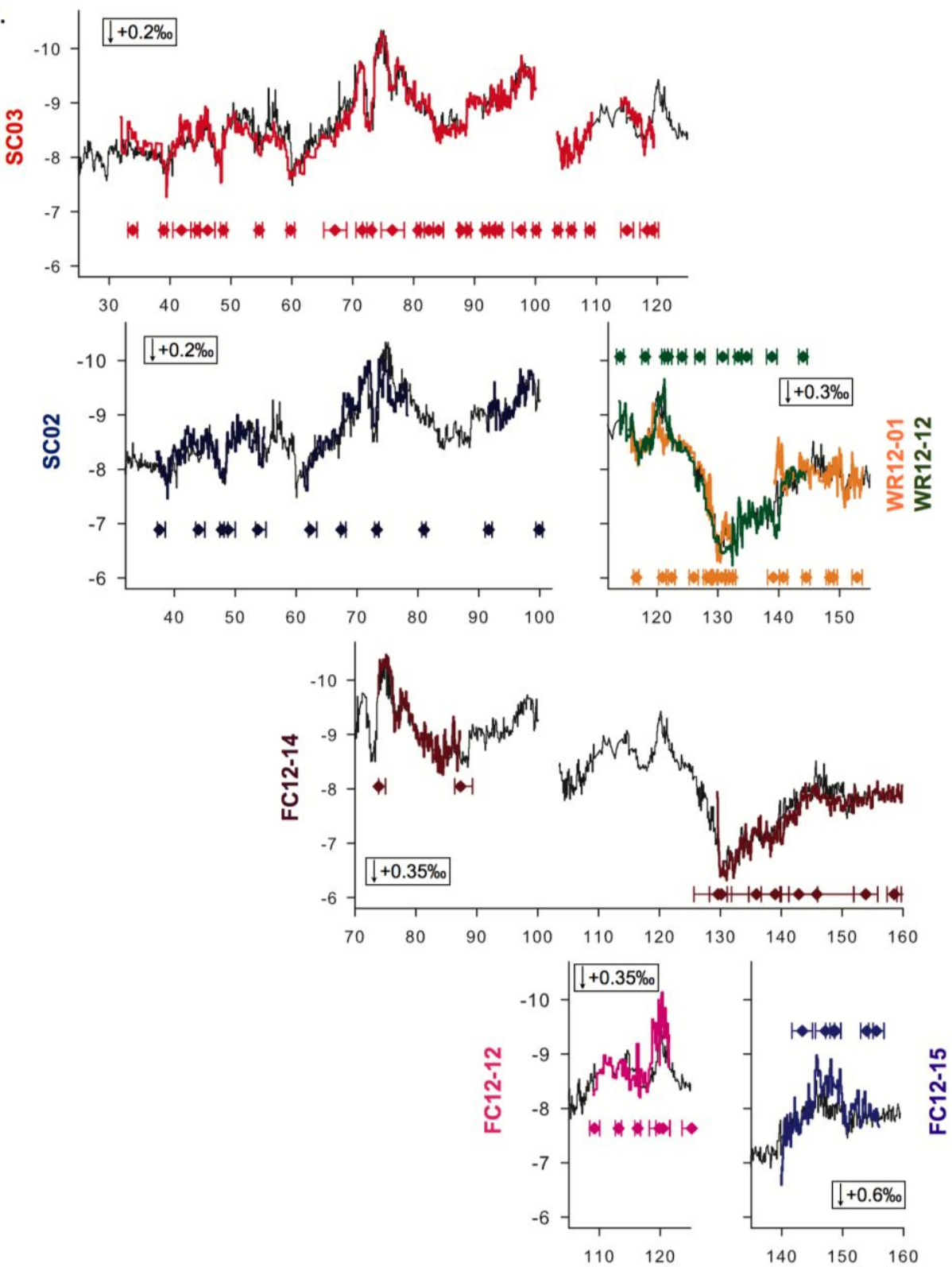

Figure 3. Composite and individual Mulu stalagmite $\delta^{18} \mathrm{O}$ records. 


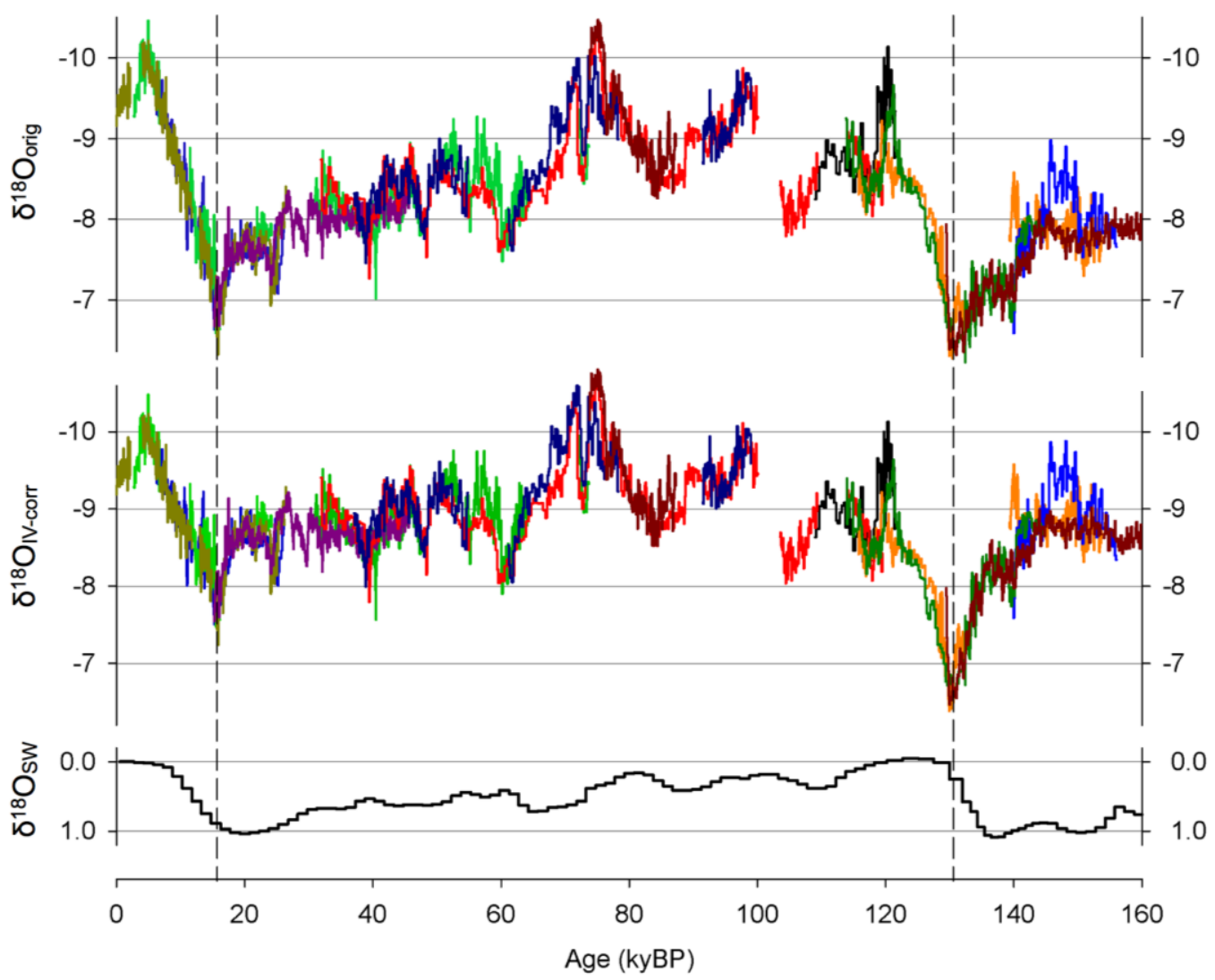

Figure 4. Original and ice-volume corrected 0-160 kybp Mulu stalagmite $\delta^{18} \mathrm{O}$ records. 


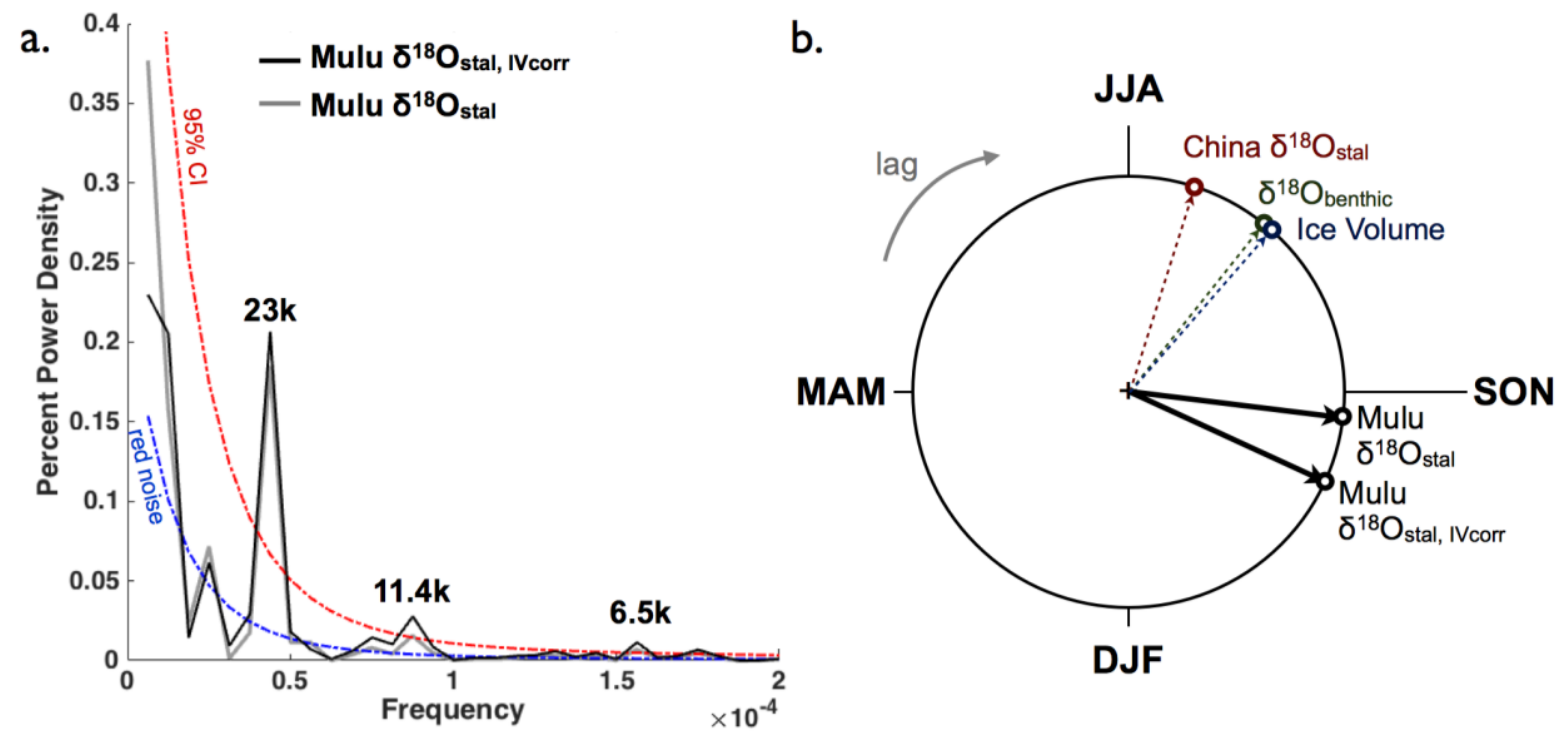

Figure 5. Mulu stalagmite $\delta^{18} \mathrm{O}$ spectral analysis and precession phase wheel summary. 

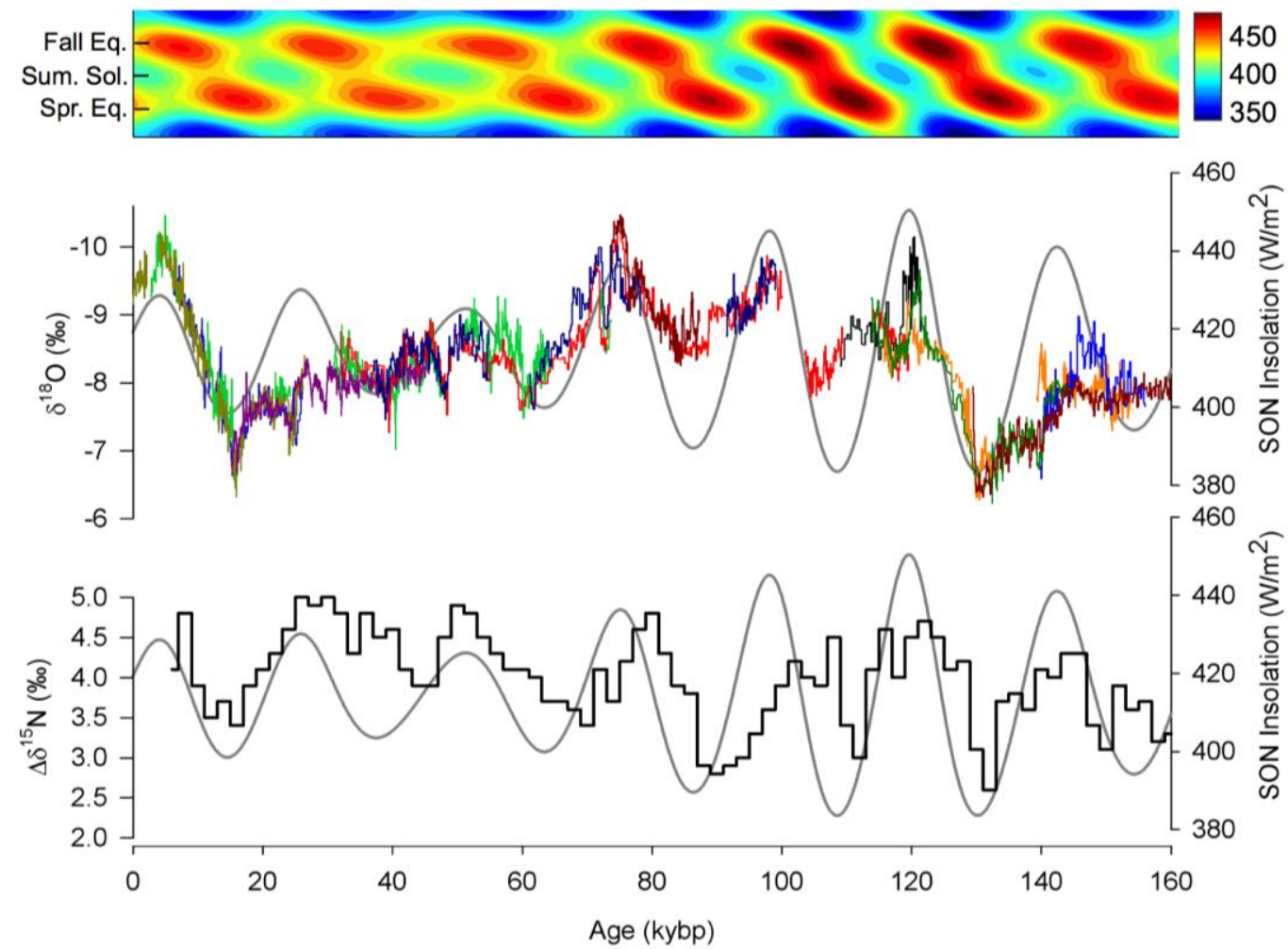

Figure 6. Comparison of both Mulu stalagmite $\delta^{18} \mathrm{O}$ records and equatorial Pacific marine sediment $\Delta \delta^{15} \mathrm{~N}$ records with $4^{\circ} \mathrm{N}$ average SON insolation. 

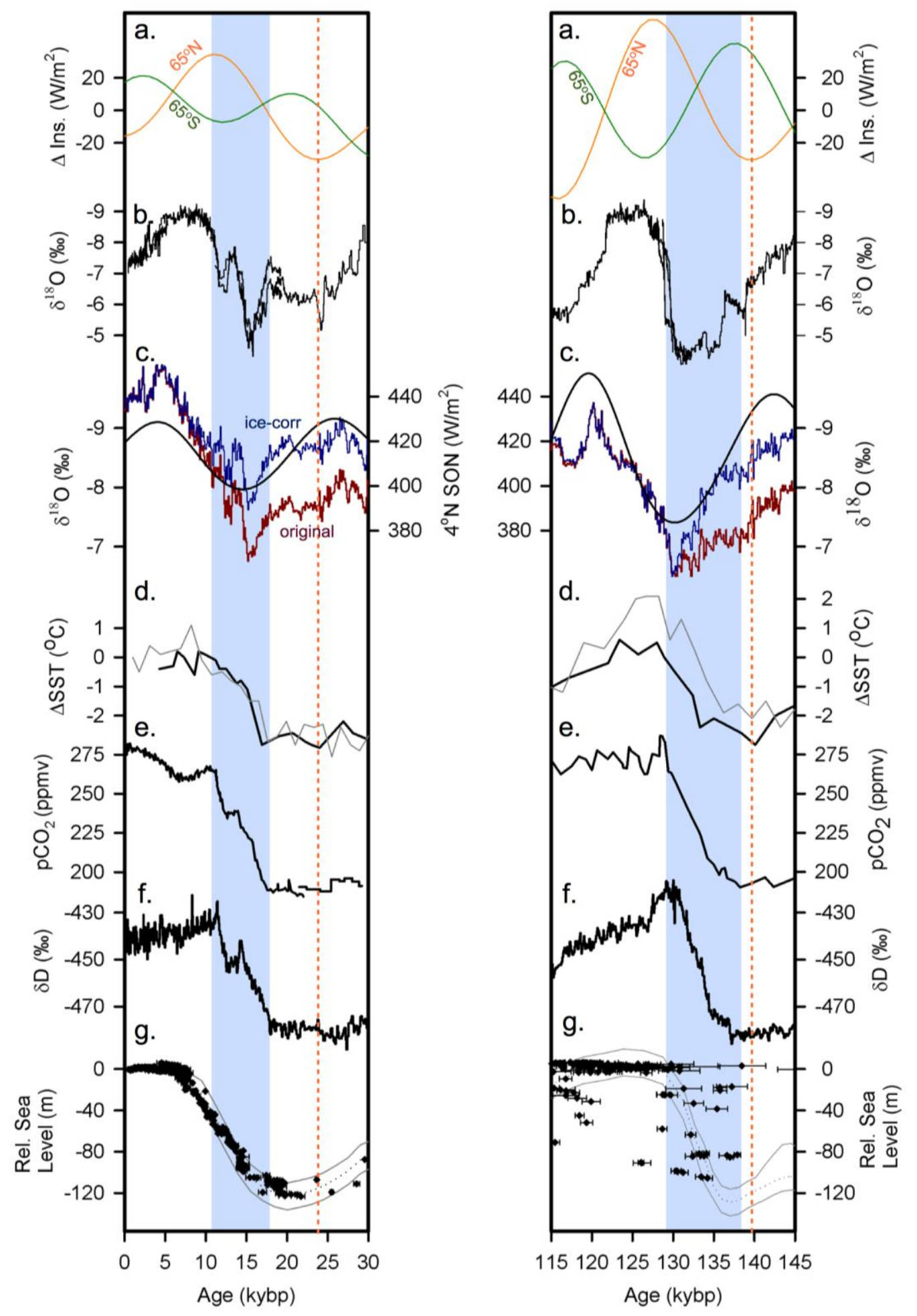

Figure 7. (left) Termination 1 paleorecord comparison. (right) Termination 2 paleorecord comparison. 


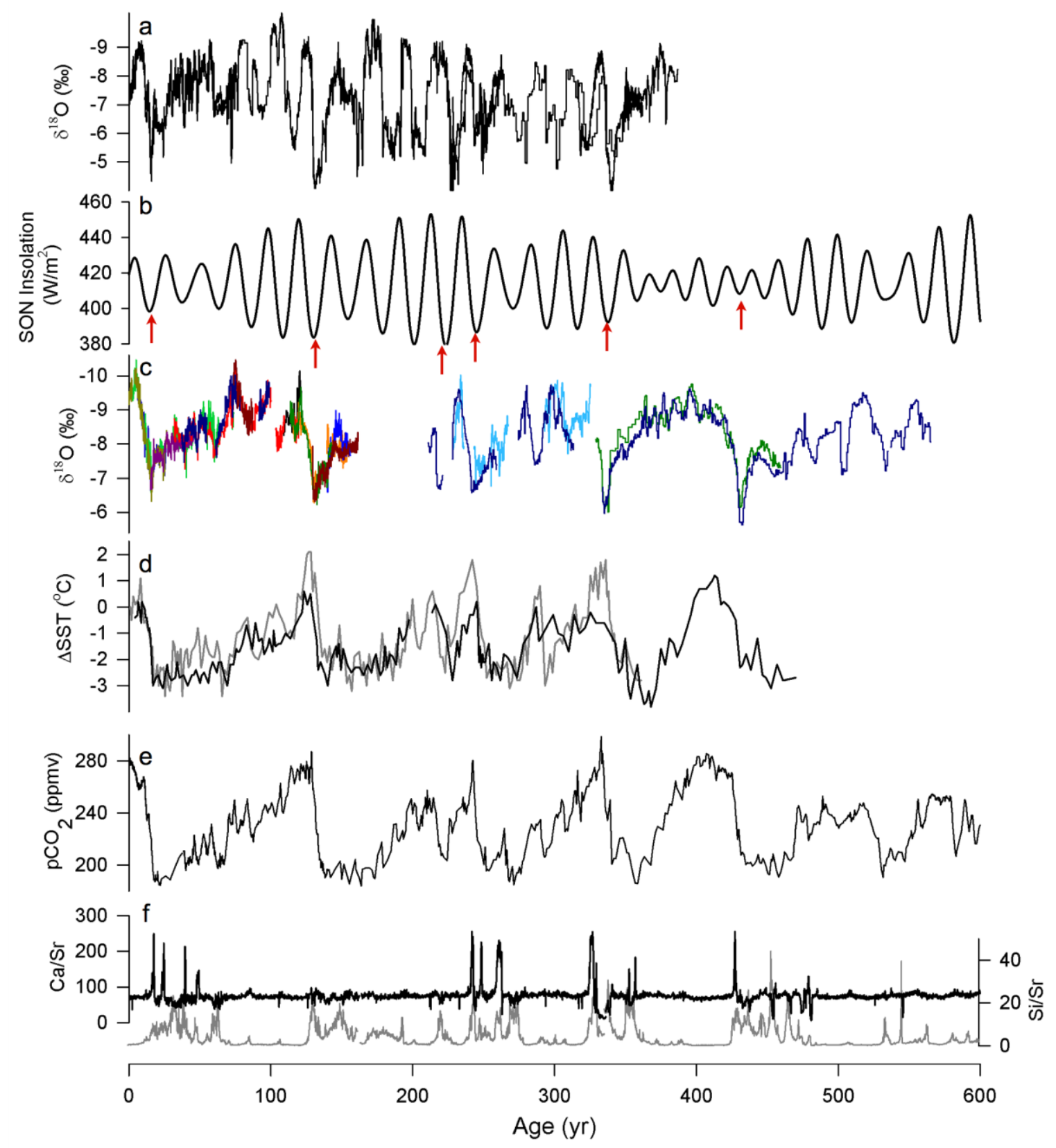

Figure 8. Comparison of 0-600 kybp global paleorecords. 